\title{
The Influence of Brand Equity, Trust, Price, PEOU, and PU on Online Based Crowdfunding Investment
}

\author{
Stefanus Yulianto ${ }^{1}$, Rinabi Tanamal ${ }^{2}$ \\ ${ }^{1,2}$ Information Technology, Universitas Ciputra, Citraland CBD Boulevard, Surabaya \\ e-mail: ${ }^{1}$ r.tanamal@ ciputra.ac.id
}

\begin{abstract}
In this modern era, a lot of that affects the behavior of people in everyday life, such as economic, social, cultural, political, and technological progress. People are beginning to rely on technology to live their activities, from transportation, interaction, browsing, learning, business affairs, to invest. This study aims to determine the effect of Brand Equity, Trust, Price, Perceived Ease of Use, and Perceived Usefulness of purchase intention in an online investment application which in this research will use the expansion of TAM. Data collection methods to be used by the authors is quantitative using questionnaires with the target respondents as much as 100 respondents, the data retrieval process using purposive sampling data. The benefit of research is to know whether Brand Equity, Trust, Price, Perceived Ease of Use, and Perceived Usefulness affect Purchase Intention in an online investment application. Data processing using SPSS regression equation results obtained as follows $\mathrm{Y}=-0.815+0,465 \mathrm{X} 1+0,248 \mathrm{X} 2-0,234 \mathrm{X} 3+0,363 \mathrm{X} 4$ $+0,406$ X5, Brand Equity becomes the most influential variables. Thus, it can be concluded that the higher brand of online investment application, so will be increasingly higher purchase intention in online investment application.
\end{abstract}

Keyword: Brand Equity, Trust, Price, TAM, Purchase Intention

\section{Introduction}

This day, the progress of the era is very rapid in the field of information technology, economic, social, cultural, and political. Especially technological advances that affect community behavior in daily activities. People are beginning to rely on technology for their activities, from interacting, browsing, learning, doing business, and also for investing.

Many are beginning to realize the importance of investment, from investment in property, gold, stocks, land, etc. But, not everyone, believes what they invest, whether it is safe, whether it will be guaranteed the value of the return as they expect.

The drive from the current state of affairs and the science that developers get out there becomes an idea wherein investments will be online using the web and mobile applications. The investment they make is not an investment that we know in general such as stocks, forex, or gold, but there are those in the fields of agriculture, land and property, etc. that connect people to buy certain commodities with a certain nominal and their own time-frame.

Investments of this kind began to emerge in 2016, but the conditions in previous years had been a lot of online transactions in Indonesia and placed Indonesia as the country with the highest online fraud in Asia with 26\% (Nurrahman, 2016), but by
2016, many start-ups are popping up and there are some who choose to make apps for investment.

Although now there are many who make transactions via online, but still many do not believe in online transactions for fear of being cheated. But there are also very happy transactions through online because of the influence of the brand of the application they used.

This study aims to examine whether the factors of Brand Equity, Trust, Price, Perceived Ease of Use, and Perceived Usefulness affect the purchase intention of the users of online investment applications.

\section{Literature Review}

Based on the conclusion the researchers took out, the researchers take a conclusion that Crowdfunding Investment Application is a useful application to help users of the application in investing crowdfunding or jointly giving their money to a company or service provider platform in the hope of getting rewards or dividends from the company.

\section{1. Brand Equity}

Brand Equity is the desire of a person to continue using a brand or not (Keller, 2008). Aaker is defines brand equity as a set of assets such as 
name, recognition, customer loyalty, perceptions of quality, and associations associated with a brand and adds value to the product being offered (Prayitno, 2010). In Aaker Model, Brand Equity has 5 components: perceived quality, brand loyalty, brand awareness, brand associations, and other proprietary brand assets (Keller, 2008). However, the five dimensions of Aaker, another exclusive brand asset, are usually omitted in brand equity research because they are not directly related to the consumer in accordance with the research of Isabel, De Chernatory and Martinez (2008): brand awareness, brand royalty, brand association, and perceived quality.

\section{2. Trust}

Trust is a belief that one party will find what the other wants rather than what the other fears. (Mao, 2010). While Alam and Norjaya (2010) argue that trust is a mutual belief of both parties between buyers and sellers that they will not exploit the weaknesses of others.

Lack of trust is the reason consumers do not relate to e-commerce sites (Pavlou, 2003). A common typology of trust built on theories of social psychology and an extensive overview of the literature of belief. This typology shows that the perception of online transaction trust is based on three components, namely: ability, benevolence, and integrity (Mayer, Davis \& Schoorman, 1995)

\section{3. Price}

Price is the amount of money charged on a product or service or the sum of the value exchanged by consumers for the benefits of owning or using the product (Kotler \& Armstrong, 2011). While the price is the only element of the marketing mix that provides income for the company (Tjiptono, 2008).

\section{4. Perceived Ease of Use}

One of the variables derived from the TAM model itself is the Perceived Ease of Use, which is used to know the level of a person to believe that the use of the system will be effortless. Perceived Ease of Use (PEOU) is used to know the level of a person to believe that in the use of the system will be free of effort (the ease) (Tanamal, 2017). There are several indicators of perceived ease of use perception: easy to learn, easy to operate, easy to use, interaction with users clear and easy to understand, flexible, easy to become expert (Fatmawati, 2015).

\section{5. Perceived Usefulness}

The Perceived Usefulness variable is intended to the extent to which a person will believe that using a particular system will improve the performance of his work. It can illustrate the system's benefits from its use in relation to various aspects. The assumption is, if a user can trust that the system can be useful, then they will use it, but otherwise if a user does not feel the system is useful, then they will not use it. There are several indicators of perceived usefulness: increasing productivity, improving / facilitating work, efficient, effective, improving performance. (Fatmawati, 2015)

\section{6. Purchase Intention}

Purchase Intention is "A model of one's attitude toward objects of goods that is very suitable in measuring attitudes toward a particular product, service or brand". Consumer buying interest is a very complex issue, but it should remain a marketer's concern. Consumer interest to buy can arise as a result of stimulus offered by the company. Each of these stimuli is designed to generate consumer buying action (Sciffman and Kanuk 2010).

\section{7. Interview}

Interview is the activity of communication between two or more people, where one person becomes an interviewer and the other becomes resources. The purpose is to get the information that needed from resources. Interviews are conducted by the interviewer by giving questions to the informant (Hareka \& Tanamal, 2018).

\section{Research Methodology}

Based on data collection techniques, the research that the researcher does, this includes quantitative research. Quantitative research itself according to Martono (2011), "research conducted by collecting data in the form of numbers. Data in the form of numbers are then processed and analyzed to obtain scientific information behind the numbers." The conclusion of the results of a study was in the form of calculations that are drawing or interlacing between variables.

\section{1. Conceptual Framework}




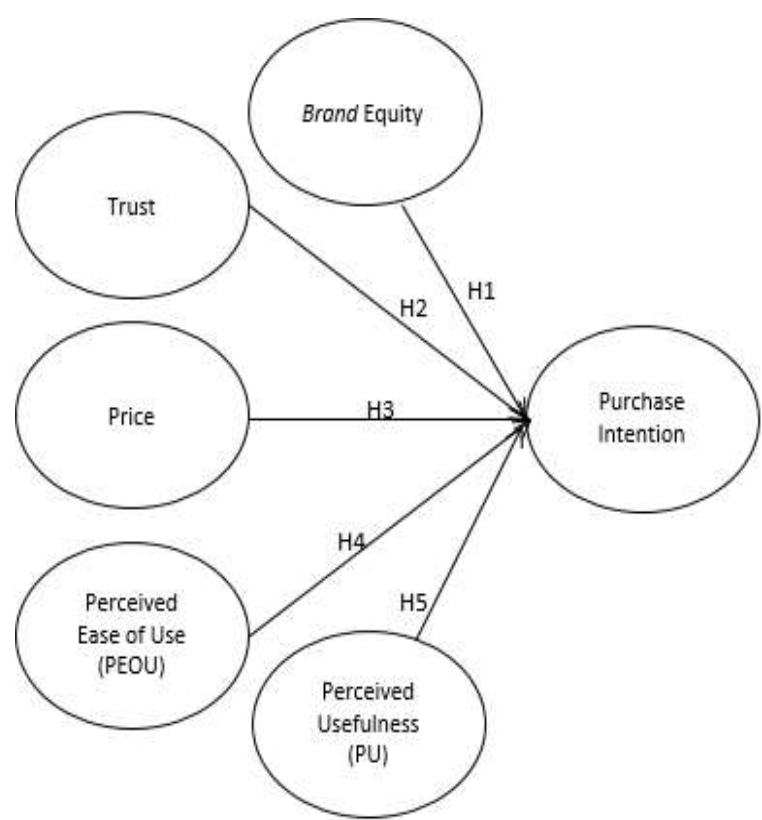

Fig. 1 Conceptual Framework

\section{2. Population and Sample}

The population in this study are the investors who apply as a customer on an online investment application. The location of this research was conducted around Surabaya. Respondents to be taken in this study are the users or investors as customers in an online investment application. Research time will be conducted from July 2017 until November 2017.

Researchers use non-probability sampling because the population of the researcher is infinite or unclear, with the aim of saving work time, effort, and cost, since the population of the study is restricted to the category of researchers. Bounded by Roscoe in Sugiyono (2011) who stated that the sample size is over 30 and less than 500, and in multivariate studies (including multiple regression analysis) the sample size should be ten times greater than the number of variables available in the study. With the foundation of the theory, researchers determine the sample size of 50 respondents. Because the researcher does face validity for 20 respondents, the results are best at 100 respondent, so the researcher determines the sample size of 100 respondent.

\section{Discussion}

\section{1. Research Objects' Overview}

Objects in this study is an application that is rampant in Indonesia is the application to invest. The application becomes an investment platform that helps the public in investing more easily, just from the reach of mobile phones only. The applications offer everything from petrified SMEs, investments in livestock, plants, to soil that all have their own applications. The investments referred to in this study are all platforms that include peer-topeer landing, crowdlending, crowdfunding, and investments that promise $15-20 \%$ profit.

\section{2. Respondent's Overview Gender}

Gender from 100 Respondents

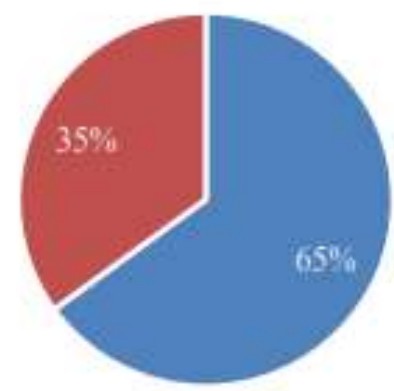

- Man . Woman

Fig. 2 Respondent Overview: Gender

From a total of 100 respondents accumulated to date, with the acquisition of Woman by $35 \%$ and Man by $65 \%$. Means as many as 35 respondents are women and 65 respondents are man.

\section{Platform}

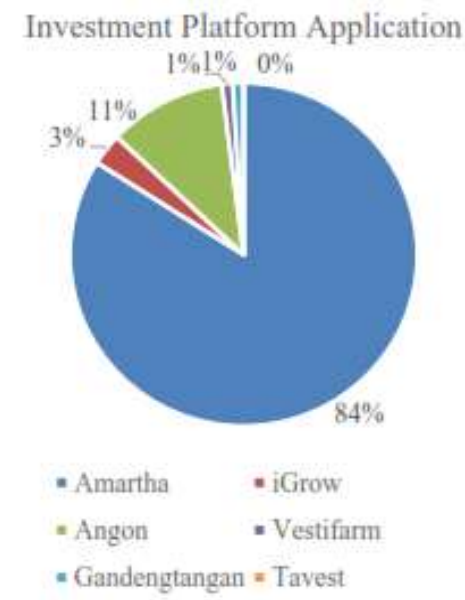

Fig. 3 Respondent Overview: Platform

From the 100 respondents, $74 \%$ or 84 respondents invested in Amartha, the second was Angon with the percentage of $17 \%$ or 11 respondents using Angon to invest, 3\% of 100 Respondents were iGrow users or as many as 3 respondents, and $1 \%$ or 1 respondent using 
"Gandeng-tangan" to invest, as well as with Vestifarm.

\section{3. Multiple Linear Regression}

In this study multiple linear regression analysis is used to find out the correlation of Brand Equity (BE), Trust (T), Price (P), Perceived Ease of Use (PEOU), and Perceived Usefulness (PU) variables to Purchase Intention expressed in equation:

$$
Y=a+b 1 \times 1+b 2 \times 2+b 3 \times 3+b 4 \times 4+b 5 \times 5+e
$$

From the multiple linear regression analysis the researcher did, it came out the result:

$$
\begin{gathered}
Y=-0,815+0,465 \times 1+0,248 \times 2-0,234 \times 3+ \\
0,363 \times 4+0,406 \times 5
\end{gathered}
$$

Looking at the results of tests that have been done, can show that 4 of 5 independent variables have a positive direction in the influence of the dependent variable in this study.

The regression coefficient for X1 (BE), X2 (T), X4 (PEOU), X5 (PU) is positive, indicating a direct relationship to the PI variable. While the variable $\mathrm{X} 3(\mathrm{P})$ has a negative influence, indicating the relationship is not unidirectional between variables $\mathrm{P}$ to variable PI. The more the price offered from an investment app, the user's purchase intentions in an investment app decrease.

\section{4. Hypothesis Test Results}

\section{Partial Significance Test Results (t test)}

\section{Variable Brand Equity (BE)}

tcount 2,925 > ttable 1,989

Sig $0.004<0.05$

From the results of this test can be said that the $\mathrm{BE}$ variable has a significant influence on Purchase Intention. Then Hypothesis 1 is accepted.

This gives the fact that the Brand Equity (BE) of the online investment application, when upgraded, is able to increase people's purchase intentions against the "stock" offered by the online investment application. By looking at the equation coefficient regression variable Brand Equity (BE) which shows a positive result that is 0.465 , means the better Brand Equity of an application, the higher the people's purchase intention in an online investment application.

The regression equation proves that the coefficient of variable X1 namely Brand Equity (BE) variable has the most significant influence to public purchase intention in online investment application, therefore the improvement and focus done on this variable will have a big impact on people's buying intention towards online investment application.

Company Policies relating to Brand Equity (BE) should be prioritized and of special concern as the results of the research show that Brand Equity (BE) has a major influence on people's purchase intentions in an online investment application.

\section{Variable Trust ( $T$ )}

tcount $2,750>$ ttable 1,989

Sig $0.007<0.05$

From the results of this test can be said that the variable $\mathrm{T}$ has a significant influence on Purchase Intention. Then Hypothesis 2 is accepted.

This provides the fact that the Trust (T) of the online investment application is enhanced, thus increasing the public's purchase intentions against the "stock" offered by the online investment application. By looking at the equation of the regression coefficient of Trust $(\mathrm{T})$ variable which shows the positive result is 0,248 , it means the better Trust from an application, hence the higher society's purchase intention in an investment application online.

\section{Variable Price $(P)$ \\ tcount $-1,912<$ ttable 1,989 \\ Sig $0.048<0.05$}

From the results of this test can be said that the variable $\mathrm{P}$ significant effect on Purchase Intention. Then Hypothesis 3 is accepted.

This provides the fact that the Price $(\mathrm{P})$ of the online investment application has a negative or opposite effect on people's buying intentions against the "stock" offered by the online investment application. By looking at the equation coefficient of variable Price $(\mathrm{P})$ regression coefficient which shows negative result is -0.234 , meaning Price $(\mathrm{P})$ variable has negative effect to people buying intention in an investment application online. Means the higher the Price of an application, the decreased purchase intention the community in an online investment applications.

Variable Perceived Ease of Use (PEOU) tcount $2.877>$ ttable 1,989

Sig $0.005<0.05$ 
From the results of this test can be said that the variable PEOU has a significant influence on Purchase Intention. Then hypothesis 4 is accepted.

This provides the fact that Perceived Ease of Use (PEOU) of the online investment application when upgraded, it is able to increase public's purchase intentions against the "stock" offered by these online investment applications. By looking at the equation of regression coefficient variable Perceived Ease of Use (PEOU) which showed a positive result that is 0.363 . This provides the fact that the Perceived Ease of Use (PEOU) or ease of use of the online investment application when upgraded, it is able to increase public's purchase intentions against the "stock" offered by these online investment applications.

\section{Variable Perceived Usefulness (PU)}

tcount 4,231> table 1,989

Sig $0,000<0.05$

From the results of this test can be said that the PU variable has a significant influence on Purchase Intention. Then hypothesis 5 is accepted.

This provides the fact that Perceived Usefulness (PU) of the online investment application when upgraded, it is able to increase public's purchase intentions against the "stock" offered by these online investment applications. By looking at the equation of regression coefficient variable Perceived Usefulness (PU) which shows the positive result is 0.406 . This provides the fact that the usefulness or function of the online investment application when upgraded, it is able to increase public's purchase intentions against the "stock" offered by these online investment applications.

\section{5. Simultaneous Significance Test Result (f Test)}

From the $\mathrm{F}$ test that has been performed using the SPSS Program. After F test, the value of Fcount is 29,296 with significance value 0.000 . With the value of Fcount 29.296 which means greater than the value of Ftable of 2.31 and a significance value of 0.000 which means smaller than 0.05. Proving that the BE, T, P, PEOU and PU variables simultaneously have a positive and significant influence on the purchase intention of investment application users in Surabaya.

\section{6. Determination Coefficient Test Results $\left(\mathbf{R}^{2}\right.$ Test)}

After the test determination coefficient $\left(\mathrm{R}^{2}\right.$ Test), note that the value adjusted $\mathrm{R}$ square of 0.588 . Thus, $58.8 \%$ of the public's intention to purchase "stock" in an investment application is influenced by Brand Equity (BE), Trust (T), Price (P), Perceived Ease of Use (PEOU), and Perceived Usefulness (PU). While the remaining 41.2\% purchase intention users in an investment application is influenced by other variables that are not examined in this study.

\section{Conclusion}

Based on the result of multiple linear regression analysis which has been done in this research, obtained regression equation as follows:

\section{$\mathrm{Y}=-\mathbf{0 , 8 1 5}+\mathbf{0 , 4 6 5} \mathrm{X} 1+0,248 \mathrm{X} 2-0,234 \mathrm{X3}+$ $0,363 \times 4+0,406$ X5}

The regression equation proves that the coefficient of the regression equation is positive. With it can be deduced as follows:

1. The influence of Brand Equity (BE) variable on the buying intention of the community in the online investment application has a positive and significant effect, can be seen through the regression coefficient value of 0.465 and get the value of tcount 2,925 with a significance value of 0.004 . With that the better the brand equity of an application, the higher the intention of buying people in online investment applications. Hence, Hypothesis 1 is accepted.

2. The influence of Trust $(\mathrm{T})$ variable on the buying intention of people in online investment application has positive and significant effect, can be seen through regression coefficient value that is equal to 0,248 and get tcount 2,750 with significance value equal to 0,007 . With it the better the level of confidence of an application, the higher the intention of buying people in online investment applications. Hence, Hypothesis 2 is accepted.

3. Influence of Price $(\mathrm{P})$ variable to purchase intention of society in online investment application have negative direction, can be seen through regression coefficient value that is equal to -0.234 and get tcount value $-1,912$ with significance value equal to 0,048 . With that price or price displayed have a negative or opposite effect on the intention of buying people in online investment applications. 
With that the higher the price of an application offered, then the intention of buying people in the application of online investment decreases. Hence, Hypothesis 3 is accepted.

Effect of Perceived Ease of Use (PEOU) variable to purchase intention of society in online investment application have positive and significant influence, can be seen through regression coefficient value that is equal to 0363 and get tcount 2,877 with significance value equal to 0.005 . With the better the level of ease of use of an application, the higher the intention of buying people in the online investment applications. Hence, Hypothesis 4 is accepted.

The influence of Perceived Usefulness (PU) variable to the buying intention of the community in online investment application has positive and significant effect, can be seen through regression coefficient value that is equal to 0,406 and get tcount 4,231 with significance value equal to 0.000 . With that the better the benefits provided from an application, the higher the intention of buying people in the online investment applications. Hence, Hypothesis 5 is accepted.

The results of the study found that the value of fcount of 29.296 which means greater than the value of Ftabel of 2.31 with a significance value of 0.000. This shows that the overall variables of Brand Equity (BE), Trust (T), Perceived Ease of Use (PEOU), and Perceived Usefulness (PU) simultaneously have a positive and significant influence on people's buying intentions in online investment applications, and the Price $(\mathrm{P})$ variable has a negative effect on the purchase intention of the community in the online investment application.

The results showed that the Brand Equity (BE) variable became the most influential variable with regression coefficient of 0.465 , and the tcount of 2.925. Thus, it can be concluded that the higher the brand equity of an online investment application, the higher the public purchase intention in the application of online investment.

\section{References}

Alam, S. S., Yasin, M. N. (2010). What Factors Influence Online Brand Trust: Evidence From Online Tickets Buyers In Malaysia. Electronic Version.hal:78-89 vol 5. Issue 3.

Buil, I., De Chernatony, L., \& Martínez, E. (2013). Examining the role of advertising and sales promotions in brand equity creation. Journal of Business Research, 66(1), 115-122.
Davis, F. D. (1989). Perceived Usefulness, Perceived Ease of Use, and User Acceptance of Information Technology. MIS Quarterly, 13(3),

Fatmawati, E. (2015). Technology Acceptance Model (TAM) Untuk Menganalisis Penerimaan Terhadap Sistem Informasi Perpustakaan. Jurnal Iqra' Volume 09 Nomer 01.

Hareka, W.A., Tanamal, R. (2018). Rancang Bangun Aplikasi Sistem Pakar Berbasis Android Untuk Memprediksi Kerusakan Pada Mesin Sepeda Motor Yamaha R25. JURTI. 2(2): 202-203.

Keller, K.L., (2008), Strategic Brand Management, 2nd Edition, Upper Saddle River, New Jersey: Pearson Prentice Hall.

Kotler, P., Armstrong, G. (2011). 10th Edition. "Marketing an Introduction". Indonesia: Pearson.

Mao, D. (2010). "A Study of Consumer Trust in Internet Shopping and the Moderating Effect of Risk Aversion in Mainland China". Hong Kong Baptist University. Journal Manajemen. 3(1) pp.1-50.

Martono, N. (2011). Metode Penelitian Kuantitatif: Analisis Isi dan Analisis Data Sekunder. Jakarta: PT. RajaGrafindo Persada.

Mayer, R.C., Davis, J. H., Schoorman, F. D. (1995). An Integratif Model of Organizational Trust, Academy of Management Review. 30 (3)

Nurrahman, Y. (2016). Penipuan Online di Indonesia Tertinggi. Retrieved from https://tekno.tempo.co/read/775347/penipuanonline-di-indonesia-tertinggi

Pavlou, P. A. (2003). Consumer Acceptance of Electronic Commerce: Integrating Trust and Risk with the Technology Acceptance Model. International Journal of Electronic Commerce, 7 (3)

Prayitno, S. (2010). Dampak Implementasi Strategi Komunikasi Pemasaran Terpadu dalam penciptaan Ekuitas Merek. Journal of Strategic Communication Vol.1, 90-112.

Schiffman \& Kanuk. (2010). Perilaku Konsumen. Jakarta: PT. INDEK.

Sugiyono. (2011). Metode Penelitian Pendidikan (Pendekatan Kuantitatid, Kualitatif, dan $R \& D)$; Alfabeta. Bandung

Tanamal, R. “Analisis Faktor Yang Paling Berpengaruh Pada Keinginan Menggunakan Aplikasi Grab Di Kota Surabaya", Jurnal Terapan Teknologi Informasi, vol. 1, no. 2, pp. 121-130, Nov. 2017.

Tjiptono, Fandy. (2008). Strategi Pemasaran. Edisi 3. Yogyakarta: Andi Offset 